\title{
Digital Skills Possessed by Secretaries for Effective Management of Information in Enugu State, Nigeria
}

\author{
Emeka Promise Ugwunwoti, Ph.D. \\ Department Of Business Education, Enugu State University of Science and Technology, (ESUT) Nigeria
}

\begin{abstract}
This study was carried out to determine the digital skills possessed by secretaries for effective management of information in Enugu State. A survey research design was used for the study. Two research questions and two null hypotheses guided the study. The population of the study consisted of 365 employers of secretaries in the private and public establishments. There was no sampling since the population was not too large. The instrument for data collection was a 35 item questionnaire titled "Digital Skills Possessed by Secretaries Questionnaire (DSPBSQ) developed by the researcher. Three experts duly validated the instrument. The reliability was done using Cronbach Alpha which yielded coefficient of 0.78 , indicating the instrument was reliable. The two research questions were answered using mean with standard deviation while the null hypotheses were tested at .05 level of significance using the two-way ANOVA. Results of the study showed that: Basic digital skills are highly possessed by secretaries in both private and public establishments in Enugu State for effective management of information. The result also revealed that advanced digital skills are fairly possessed by secretaries in both private and public establishments in Enugu State for effective management of information. Based on the findings, it was recommended that, there should be regular seminars and workshops skills for secretaries. Again, employers of labour should provide ICT's to their secretaries as working tools.
\end{abstract}

Keywords: Digital Skills, Secretaries, Effective Management and Information

DOI: $10.7176 / \mathrm{IKM} / 11-4-11$

Publication date:September $30^{\text {th }} 2021$

\section{INTRODUCTION}

The information revolution coupled with the attendant technologies have changed the nature of business and its operations. Today information management, are exchanged digitally. Hence, the need for information managers particularly secretaries in various establishments to possess the needed digital skills. A secretary is an individual with secretarial knowledge employed in an establishment to assist with correspondence, make appointments and carryout administrative tasks. According to Ojobor and Musa (2005) in Ugwunwoti (2019), a secretary is that person who maintains a high standard of confidentially, a repository of information. The National Secretaries Association (International) in Ngwoke (2019), defined a secretary as an assistant to an executive, possessing mastery of office skills and ability to assure responsibility without direct supervisions the author further stated that, the secretary displays initiative, exercise judgment and make decision within the scope of her authority. This implies that a secretary is responsible for managing information in any establishment.

Managing information is making sure that the right people have the right information at the right time (Ugwunwoti, 2021). The author further opined that, managing information describes how successful organization make best use of information and knowledge. Moreover, Obayi (2020), was of the view that information management is the collection and management of information from one or more source and the distribution of that information to one or more audience. No good establishment can manage information without the services of a secretary with bias in digital skills. Digital skills are the abilities to use digital devices, communication application and networks to access and manage information. According to Umoru (2019), digital skills refers to skills related to the use of technology. According to Cornell University Digital Literacy Resource (2019), digital skill is the ability to find, evaluate, utilize, share and create content using technologies and the internet. With the digital skills, a lot of work can be down from home, offices or on the move by secretaries. All these are geared toward managing information.

International Finance Corporation (IFC) (2019) predicted that over 230 million jobs in sub-Saharam African will need digital skills by 2030. The world Bank Group Office Accra, Ghana (2019), stated that a global digital revolution is underway and is likely to bypass Africa. No wonder, World Bank (2018), opined that digital skills is a driver of economic growth and competitiveness. In this context, digital skills which secretaries should possess for effective management of information are basic and advanced digital skills respectively. Basic digital skills are skills that secretaries in both private and public establishments should possess for effective management of information. According to Umoru (2019), basic digital skills are entry level functional skills 
required to make rudimentary use of digitals tools and applications. UK Department for Education (DIE) (2019) stated that, basic digital skills are for life and additional skills to work. No wonder, Atapka (2012) opined that digital telephone and office electronically powered machined have reduced the long hours of office business to a mere pressing of buttons to attain, a more effective and efficient output. With basic digital; skills, secretaries print document correctly, participate on social media among others. Apart from basic digital skills, advanced digital skills should be possessed by the secretaries.

Advanced digital skills in other hand are the group of skills that form the bases of specialist (Information and Communication Technology occupations and professions is (Umoru, 2019). These are needed by secretaries. This is in line with Ugwunwoti (2018), that employers of labour demand graduates who are prepared to leverage technology in a scalable fashion to advance their organization strategies and operations. The use of ICT has virtually changed almost all dimensions of office functions that have to do with communication, information and records management (Ile, 2010). Advanced digital skills, therefore are the abilities to perform special tasks and professions in the information and communication technology. A good secretary with advanced digital skills should have the knowledge of computer language programming, cloud computing, network management among others for effective management of information in any contemporary establishment.

An establishment is a place or organization where people do businesses. There are both private and public establishments. Private establishments are owned, financed and controlled by government (Ugwunwoti, 2018). According to Enugu State Summary of Business Directory (2020), there are 74 establishments with 365 employers of secretaries. Some of employers are experienced while others are less experienced. Experience is a vital variable in managing information. Experience is the process of getting; knowledge or skill that is obtained from doing, seeing or feeling things. It is the process through which conscious organizations perceive the world around them. Udoye (2013) reported that, there was significant difference in the mean ratings of experienced and less experienced employers on modern office job competencies in their establishments. Experienced employers of secretaries in this context are those that have ten years and above and less experienced employers of secretaries (those who have been 1-9 years). Despite, the important attached to the digital skills in various establishments in Enugu State, the needed results are yet to been done by secretaries. It is against this background that, this work on digital skills possessed by secretaries for effective management of information in Enugu State was carried out.

\section{Statement of the Problem}

Digital skills are the abilities to use devices, communication application and networks to access and manage information. Moreover, managing information is making sure that the right people have the right information at the right time. With the digital skills, information can be managed from home or on move by secretaries. The world has changed, the way information is managed has changed and the secretaries have to change. But a careful observation by the researcher shows that the secretaries seem not to have embraced digital technology, particularly for information management in establishments. The problem of the study was that secretaries in Enugu State seem not have the needed digital skills. Therefore, it become vital to ascertain the opinion of employers of secretaries in private and public establishments on digital skills possessed by their secretaries for effective managing of information in Enugu State.

\section{Purpose of the Study}

The main purpose of the study was to determine the digital skills possessed by secretaries for effective management of information in Enugu State, Nigeria. Specifically, the study sought to:

1. determine the basic digital skills possessed by secretaries for effective management of information in Enugu State and;

2. determine the advanced digital skills possessed by secretaries for effective management of information in Enugu State.

\section{Research Questions}

The following research questions guide the study. 
1. To what extent do experienced and less experienced employers in private and public establishments in Enugu State perceive the basic digital skills possessed by their secretaries for effective management of information?

2. To what extent do experienced and less experienced employers in private and public establishments in Enugu State perceive the advanced digital skills possessed by their secretaries for effective management of information?

\section{Research Hypotheses}

The following null hypotheses were tested at .05 level of significance using a two-way ANOVA.

$\mathrm{Ho}_{1}$ : There is no significant difference between the mean ratings of experienced and less experienced employers in private and public establishments in Enugu State regarding the digital skills possessed by their secretaries for effective management of information.

$\mathrm{Ho}_{2}$ : Experienced and less experienced employers in Enugu State do not differ significantly in their mean ratings of advanced digital skills possessed by their secretaries for effective management of information.

\section{Method}

A descriptive survey research design was employed in this study. According to Okoro and Odesanya (2019), survey design is a method of sociological investigation that uses question based on statistical surveys to collect information about how people think and act. But according to Nworgu (2015), survey design is one in which a group of people or items are studied by collecting and analyzing data from only a few people or item considered to be representative of the entire population.

The study was carried out in private and public establishments in Enugu State of Nigeria. Enugu State is one of the states in the South-East geo-political zone of Nigeria. The researcher chose Enugu State for this study because the State has many establishments that employ secretaries.

The population for the study consisted of 365 employers of labour (secretaries) in 74 establishments in Enugu State (Enugu State Summary of Business Directory, 2020). The establishments comprised of private and public owned establishments. The entire 365 employers of labour in the 74 establishments ( 200 from private and 165 from public establishments) respectively were used for the study. Thus, there was no sampling since the population was manageable.

One research instrument was used to collect data for the study. This was a structured questionnaire (Digital Skills Possessed By Secretaries Questionnaire, DSPBSQ) with items developed by the researcher through the aid of established literature on digital skills. The questionnaire consisted of two sections: Section A elicits data on demographic data of the respondents. Section B has two clusters; Cluster 1, Basic digital skills and Cluster 2, Advanced digital skills. The items in DSPBSQ was structured on a 4-point rating scale with numerical values: Very Highly Possessed (VHP) - 4; Highly Possessed (HP) - 3, Fairly Possessed (FP) - 2 and Low possessed (LP) - 1 .

The instrument was validated by three experts. Their comments and suggestions were used in modifying the final instrument. To ascertain the reliability of the items, the instrument was administered on 20 employers of secretaries in public and private establishments in Ebonyi State. The overall reliability index for the instrument was 0.78 ; the instrument was therefore, considered reliable.

The researcher administered the questionnaire to the respondents with an introduction letter and with the help of ten research assistants. They helped the researcher in retrieving the completed copies of the questionnaire; which was subjected to inspection.

Mean and standard deviation was used in answering the research questions, while the hypotheses were tested at .05 level of significance using two-way ANOVA. The decision rule for answering the research questions was based on the upper and lower limits of the mean; thus: Very highly possessed (3.50-4.00); Highly possessed (2.50-3.49); Fairly possessed (1.50-2.49) and Lowly possessed (1.00-1.49).

The null hypothesis not rejected when F-calculated was less than or equal to the critical F-ratio, but rejected when the F-calculated exceeded the critical F-ratio. 


\section{Results:}

Research Question 1: To what extent do experienced and less experienced employers in private and public establishments in Enugu State perceive the Basic digital skills possessed by their secretaries for effective management of information.

Table 1: mean ratings and standard deviation on Basic digital skills possessed by secretaries for effective management of information in establishments in Enugu State, Nigeria.

\begin{tabular}{|c|c|c|c|c|c|c|c|c|c|c|c|c|c|c|c|c|}
\hline \multirow[t]{3}{*}{$\mathrm{S} / \mathrm{N}$} & \multirow{3}{*}{$\begin{array}{l}\text { Basic digital } \\
\text { skills includes } \\
\text { the abilities } \\
\text { to: }\end{array}$} & \multicolumn{6}{|c|}{ Public establishments } & \multicolumn{7}{|c|}{ Private establishments } & \multicolumn{2}{|c|}{ Overall } \\
\hline & & \multicolumn{3}{|c|}{ Experienced } & \multicolumn{3}{|c|}{ Less-experienced } & \multicolumn{3}{|c|}{ Experienced } & \multicolumn{4}{|c|}{ Less-experienced } & \multirow[b]{2}{*}{ SD } & \multirow[b]{2}{*}{ Dec } \\
\hline & & $\bar{X}$ & SD & Dec & $\bar{X}$ & $\mathrm{SD}$ & Dec & $\bar{X}$ & SD & Dec & $\bar{X}$ & SD & Dec & $\bar{X}$ & & \\
\hline 1 & $\begin{array}{l}\text { Input data } \\
\text { correctly in a } \\
\text { system. }\end{array}$ & 3.36 & 0.48 & $\mathrm{HP}$ & 3.20 & 0.61 & $\mathrm{HP}$ & 3.11 & 0.91 & HP & 3.49 & 0.91 & VHP & 3.29 & 0.88 & HP \\
\hline 2 & $\begin{array}{l}\text { Manipulate } \\
\text { the computer } \\
\text { keyboard }\end{array}$ & 2.99 & 0.92 & $\mathrm{HP}$ & 3.20 & 0.73 & HP & 3.47 & 1.00 & HP & 3.18 & 1.00 & HP & 3.25 & 0.93 & HP \\
\hline 3 & $\begin{array}{l}\text { Edit } \\
\text { document in } \\
\text { the computer } \\
\text { keyboard }\end{array}$ & 3.05 & 0.84 & HP & 2.61 & 0.92 & HP & 2.84 & 1.19 & HP & 2.66 & 1.19 & HP & 2.79 & 1.14 & HP \\
\hline 4 & $\begin{array}{l}\text { Format } \\
\text { document }\end{array}$ & 2.96 & 0.69 & HP & 2.64 & 0.81 & HP & 2.80 & 1.22 & HP & 2.88 & 1.22 & HP & 2.82 & 1.18 & HP \\
\hline 5 & $\begin{array}{l}\text { Reformat } \\
\text { document }\end{array}$ & 2.66 & 0.56 & HP & 2.66 & 0.68 & HP & 2.55 & 1.28 & HP & 2.61 & 1.28 & HP & 2.62 & 1.20 & HP \\
\hline 6 & $\begin{array}{l}\text { Send } \\
\text { electronic } \\
\text { mails }\end{array}$ & 2.51 & 0.91 & HP & 2.52 & 1.28 & HP & 2.64 & 1.22 & HP & 2.61 & 1.22 & HP & 2.57 & 1.16 & HP \\
\hline 7 & $\begin{array}{l}\text { Generate } \\
\text { electronic } \\
\text { mail (e-mails) }\end{array}$ & 2.68 & 1.21 & HP & 2.96 & 1.11 & HP & 2.98 & 0.91 & HP & 2.74 & 0.91 & HP & 2.84 & 1.13 & HP \\
\hline 8 & $\begin{array}{l}\text { Print } \\
\text { document } \\
\text { correctly }\end{array}$ & 2.45 & 1.28 & FP & 2.00 & 0.86 & FP & 2.19 & 0.96 & HP & 2.28 & 0.96 & FP & 2.23 & 1.14 & FP \\
\hline 9 & $\begin{array}{l}\text { Browse the } \\
\text { internet }\end{array}$ & 2.87 & 1.16 & $\mathrm{HP}$ & 2.99 & 0.96 & HP & 3.01 & 1.18 & HP & 2.61 & 1.18 & HP & 2.87 & 1.17 & HP \\
\hline 10 & $\begin{array}{l}\text { Use } \\
\text { electronic } \\
\text { data security }\end{array}$ & 2.60 & 1.24 & HP & 2.50 & 1.22 & HP & 2.52 & 0.91 & HP & 2.70 & 0.91 & HP & 2.58 & 1.21 & HP \\
\hline 11 & $\begin{array}{l}\text { Scan } \\
\text { document } \\
\text { using the } \\
\text { scanner }\end{array}$ & 3.25 & 1.01 & HP & 3.61 & 0.98 & VHP & 3.38 & 0.91 & VHP & 2.84 & 0.91 & HP & 3.27 & 0.96 & HP \\
\hline 12 & $\begin{array}{l}\text { Notify } \\
\text { relevant } \\
\text { information } \\
\text { via internet. }\end{array}$ & 3.15 & 0.89 & HP & 3.38 & 0.98 & HP & 3.10 & 0.90 & HP & 3.41 & 0.90 & HP & 3.26 & 0.96 & HP \\
\hline 13 & $\begin{array}{l}\text { Keep } \\
\text { passwords } \\
\text { secure }\end{array}$ & 2.98 & 1.11 & HP & 3.00 & 1.12 & HP & 2.66 & 1.18 & HP & 3.04 & 1.18 & HP & 2.92 & 1.15 & HP \\
\hline 14 & $\begin{array}{l}\text { Participate on } \\
\text { social media }\end{array}$ & 2.60 & 1.19 & HP & 2.81 & 0.91 & HP & 2.58 & 1.24 & HP & 2.81 & 1.26 & HP & 2.70 & 1.19 & HP \\
\hline 15 & $\begin{array}{l}\text { Present } \\
\text { solutions } \\
\text { through }\end{array}$ & 2.09 & 0.97 & FP & 1.96 & 1.08 & FP & 2.41 & 0.98 & FP & 2.30 & 0.94 & FP & 2.19 & 0.97 & FP \\
\hline
\end{tabular}




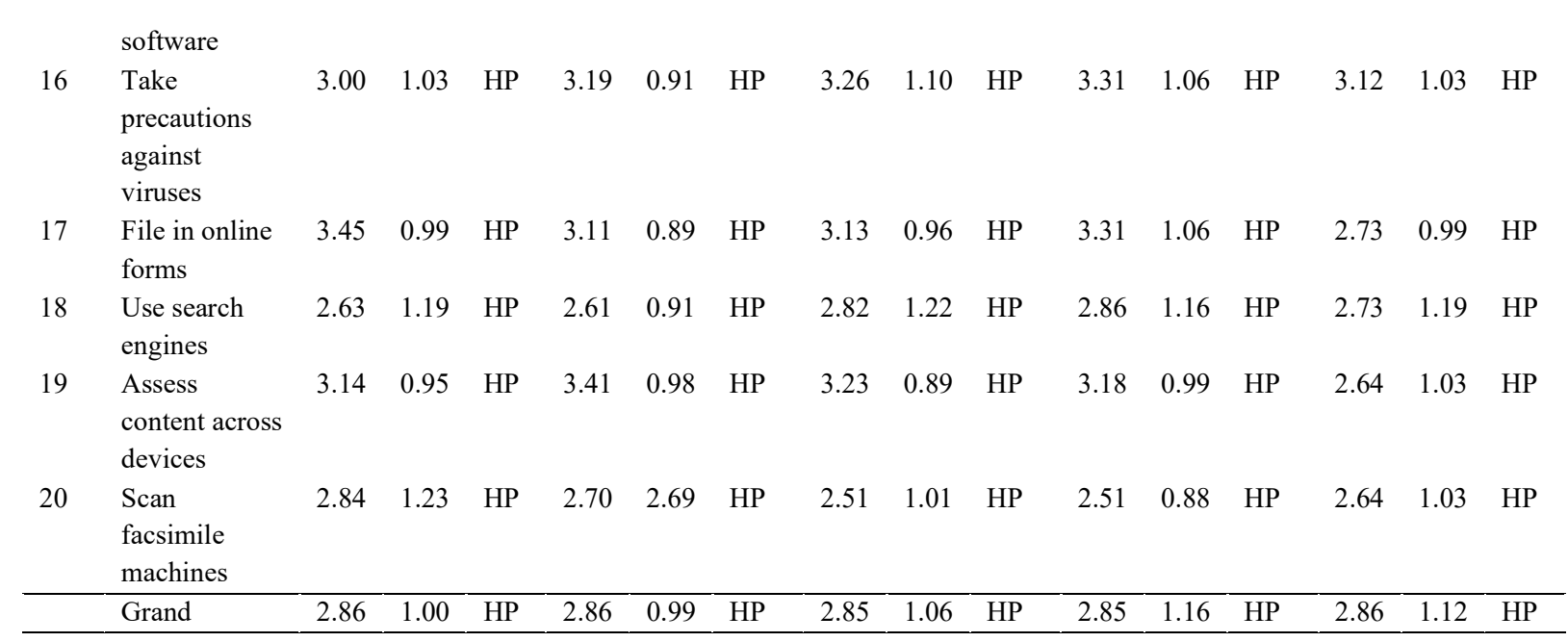

The results in Table 1 shows that, secretaries in public establishments possessed 18 out of the 20 basic digital skills at high level, while they fairly possessed only 2 basic digital skills in private establishments. Experienced and less-experienced employers were of the view that their secretaries highly possessed 2 of them. The overall mean scores show that all secretaries put together highly possessed only 18 skills while they fairly possessed 2 of them.

Hypothesis 1

There is no significant difference between the mean ratings of experienced employers in public and private establishments in Enugu State regarding the basic digital skills possessed by their secretaries for effective management of information.

Table 2:

Two-way ANOVA summary table for the difference between the mean ratings of experienced and less experienced employers in private and public establishments in Enugu state regarding the basic skills.

\begin{tabular}{|c|c|c|c|c|c|c|}
\hline Source & Sum of square & df & Mean square & $\mathbf{F}$ & Sig & Dec \\
\hline Corrected model & 37.103 & 3 & 12.368 & 12.450 & 0.000 & \\
\hline Intercept & 1218.142 & 1 & 1218.142 & 1227.000 & 0.00 & \\
\hline Experience & 1.959 & 1 & 1.959 & 1.972 & 0.126 & NS \\
\hline Type of Establishment & 0.894 & 1 & 0.894 & 0.900 & 0.372 & NS \\
\hline Experience by type of establishment & 1.961 & 1 & 1.961 & 1.975 & 0.096 & NS \\
\hline Error & 361.452 & 364 & 0.993 & & & \\
\hline Total & 1935.101 & 360 & & & & \\
\hline Corrected Total & 402.575 & 359 & & & & \\
\hline
\end{tabular}

Table 2 shows that, experienced F-calculated value of 1.972 is significant at 0.126 which is higher than the 0.05 level of significance set for this study. Hence, experience is not significant. This means there is no significance between the mean ratings of experienced employers regarding basic digital skills possessed by them. For type of establishment, the F-calculated value of 0.900 is significant at 0.372 which is higher than the 0.05 level of significant i.e. there is no significant difference between the mean ratings of employers in public and private establishments regarding basic digital skills possessed by their secretaries. Interaction effect (experienced by location) is not significant. Therefore, there is difference between the mean ratings of experienced and less experienced employers in public establishments in Enugu State.

\section{Research Question 2}

To what extent do experienced and less experienced employers in private and public establishments in Enugu State perceive the Advanced digital skills possessed by their secretaries for effective management of information? 
Table 3:

Mean ratings and standard deviations on Advanced digital skills possessed by secretaries for effective management of information in Enugu State.

\begin{tabular}{|c|c|c|c|c|c|c|c|c|c|c|c|c|c|c|c|c|}
\hline \multirow[t]{3}{*}{$\mathrm{S} / \mathrm{N}$} & \multirow{3}{*}{$\begin{array}{l}\text { Advanced digital skills } \\
\text { includes the abilities } \\
\text { to: }\end{array}$} & \multicolumn{6}{|c|}{ Public establishments } & \multicolumn{7}{|c|}{ Private establishments } & \multicolumn{2}{|c|}{ Overall } \\
\hline & & \multicolumn{3}{|c|}{ Experienced } & \multicolumn{3}{|c|}{ Less-experienced } & \multicolumn{3}{|c|}{ Experienced } & \multicolumn{4}{|c|}{ Less-experienced } & \multirow[b]{2}{*}{ SD } & \multirow[b]{2}{*}{ Dec } \\
\hline & & $\bar{X}$ & SD & Dec & $\bar{X}$ & $\mathrm{SD}$ & Dec & $\bar{X}$ & SD & Dec & $\bar{X}$ & SD & Dec & $\bar{X}$ & & \\
\hline 21 & $\begin{array}{l}\text { Use professional } \\
\text { software for } \\
\text { presentation. }\end{array}$ & 2.68 & 1.16 & HP & 2.42 & 0.96 & FP & 2.81 & 0.99 & HP & 2.45 & 1.14 & FP & 2.59 & 1.11 & HP \\
\hline 22 & $\begin{array}{l}\text { Use professional } \\
\text { software for } \\
\text { accounting. }\end{array}$ & 2.72 & 0.89 & HP & 2.31 & 1.16 & FP & 2.81 & 0.92 & HP & 2.24 & 1.12 & FP & 2.52 & 1.10 & HP \\
\hline 23 & $\begin{array}{l}\text { Use professional for } \\
\text { project management. }\end{array}$ & 2.70 & 0.88 & HP & 2.37 & 1.15 & FP & 2.68 & 0.93 & HP & 2.41 & 1.16 & FP & 2.54 & 1.09 & HP \\
\hline 24 & $\begin{array}{ll}\text { Apply } & \text { digital } \\
\text { marketing } & \end{array}$ & 2.58 & 0.69 & HP & 1.74 & 1.20 & FP & 2.66 & 0.88 & HP & 2.18 & 1.18 & FP & 2.29 & 1.12 & FP \\
\hline 25 & $\begin{array}{l}\text { Knowledge of social } \\
\text { media analysis }\end{array}$ & 2.66 & 0.93 & HP & 2.28 & 1.17 & FP & 2.70 & 0.86 & HP & 1.96 & 1.13 & FP & 2.40 & 1.11 & FP \\
\hline 26 & $\begin{array}{l}\text { Knowledge of web } \\
\text { design }\end{array}$ & 2.59 & 1.10 & HP & 2.46 & 0.98 & FP & 2.66 & 1.13 & HP & 2.05 & 0.92 & FP & 2.44 & 1.09 & FP \\
\hline 27 & $\begin{array}{l}\text { Knowledge of graphic } \\
\text { design }\end{array}$ & 2.72 & 1.19 & HP & 2.56 & 1.17 & HP & 2.81 & 1.16 & HP & 2.51 & 1.19 & HP & 2.65 & 1.18 & HP \\
\hline 28 & $\begin{array}{l}\text { Knowledge of } \\
\text { computing language } \\
\text { programming }\end{array}$ & 2.96 & 0.81 & HP & 2.61 & 1.13 & FP & 3.00 & 1.15 & HP & 2.71 & 0.91 & FP & 2.82 & 1.12 & FP \\
\hline 29 & Cloud computing & 3.21 & 1.09 & HP & 2.61 & 1.19 & HP & 3.16 & 1.11 & HP & 2.71 & 1.20 & HP & 2.82 & 1.17 & HP \\
\hline 30 & $\begin{array}{l}\text { Knowledge of network } \\
\text { management }\end{array}$ & 2.82 & 1.11 & HP & 1.70 & 1.20 & FP & 2.63 & 1.00 & HP & 2.41 & 1.16 & FP & 2.39 & 1.14 & FP \\
\hline 31 & $\begin{array}{l}\text { Knowledge of } \\
\text { artificial intelligence }\end{array}$ & 2.06 & 1.01 & HP & 2.06 & 1.16 & FP & 2.00 & 0.98 & FP & 1.92 & 1.12 & FP & 2.01 & 1.05 & FP \\
\hline 32 & $\begin{array}{l}\text { Knowledge of cyber } \\
\text { security }\end{array}$ & 2.61 & 1.19 & HP & 2.43 & 1.19 & FP & 2.52 & 0.99 & HP & 2.36 & 1.16 & FP & 2.48 & 1.18 & FP \\
\hline 33 & $\begin{array}{l}\text { Knowledge of web } \\
\text { development }\end{array}$ & 1.98 & 1.16 & FP & 2.42 & 1.02 & FP & 2.20 & 1.09 & FP & 2.00 & 1.80 & FP & 2.15 & 0.98 & FP \\
\hline 34 & $\begin{array}{l}\text { Security engine } \\
\text { optimization }\end{array}$ & 2.50 & 0.89 & HP & 1.86 & 1.06 & FP & 2.58 & 0.96 & HP & 1.66 & 1.00 & FP & 2.15 & 0.98 & FP \\
\hline 35 & $\begin{array}{l}\text { Knowledge of } \\
\text { performance } \\
\text { measurement }\end{array}$ & 2.62 & 0.97 & FP & 2.50 & 1.16 & HP & 2.58 & 1.01 & FP & 2.46 & 1.14 & FP & 2.45 & 1.12 & HP \\
\hline 36 & Grand Mean & 2.61 & 1.10 & HP & 2.29 & 1.15 & FP & 2.65 & 1.03 & HP & 2.25 & 1.12 & FP & 2.45 & 1.16 & FP \\
\hline
\end{tabular}

Table 3 shows that experienced employers of secretaries in public establishments agreed that their secretaries highly possessed 13 of the advanced digital skills while they fairly possessed 2. Less experienced employers of secretaries in the same public shows that their secretaries highly possessed only 4 advanced digital skills Employers in public establishments were of view that their secretaries are highly possessed 13 advanced digital skills and fairly possess 2 of them. Less experienced employers in private counterparts agree that their secretaries highly possessed 3 of the advanced digital skills and fairly possessed 12. The overall mean scores show that all employees put together possess 7 of the advanced digital skills and fairly possess 8 .

\section{Hypothesis 2}

Experienced and less experienced employers in Enugu State do not differ significantly in their mean ratings of advanced digital skills possessed by their secretaries for effective management of information. 
Table 4:

Two-way ANOVA difference between the mean ratings of experienced and less experienced employers in public and private establishments regarding the advanced digital skills possessed by their secretaries in Enugu State.

\begin{tabular}{|c|c|c|c|c|c|c|}
\hline Source & Sum of square & df & Mean square & $\mathbf{F}$ & Sig & Dec \\
\hline Corrected model & 3.142 & 3 & 1.047 & 12.450 & 0.000 & \\
\hline Intercept & 786.036 & 1 & 786.036 & 1227.000 & 0.00 & \\
\hline Experience & 5.277 & 1 & 5.277 & 1.972 & 0.126 & NS \\
\hline Type of Establishment & 0.904 & 1 & 0.904 & 0.900 & 0.372 & NS \\
\hline Experience by type of establishment & 1.233 & 1 & 1.233 & 1.975 & 0.096 & NS \\
\hline Error & 244.244 & 364 & 0.993 & & & \\
\hline Total & 1341.000 & 360 & & & & \\
\hline Corrected Total & 250.223 & 359 & & & & \\
\hline
\end{tabular}

Table 4 shows that experience with F-calculated value of 7.864 is significant at 0.000 which is lesser than 0.05 level of significance set for this study. Thus, experience is a significant i.e. there is a significant difference between the mean ratings of experienced and less experienced employers in Enugu State regarding advanced digital skills possessed by their employees. For type of establishment, the F-calculated value of 1.347 was found significant at 0.096 which is higher than the 0.05 level of significance set for this study. Thus, type of establishment is not significant. Hence, there is no significant difference between the mean ratings of public and private employers in Enugu State with respect to advanced digital skills possessed by their secretaries. Interaction effect (experience by type of institution is not significant. This means that there is no significant difference between the mean ratings of experienced and less experienced employers in public and private establishments in Enugu State with respect to advanced digital skills possessed by their employees.

\section{Summary of Major Findings}

Results of data analysis relating to the study showed the following:

1. Basic digital skills are highly possessed by secretaries in both public and private establishments in Enugu State for effective management of information.

2. There is no significant difference between the mean ratings of experienced and less experienced employers in public and private establishments in Enugu State regarding the basic digital skills possessed by their secretaries for effective management of information.

3. Advanced digital skills are fairly possessed by secretaries in both private and public establishments in Enugu State for effective management of information.

4. Experienced and less experienced employers in Enugu State do not differ significantly in their mean ratings of advanced digital skills possessed by their secretaries for effective management of information.

\section{Discussion of Findings}

The result of the study with respect to research question one revealed that, employers of secretaries in both private and public establishments in Enugu State were of the opinion that basic digital skills were highly possessed by their secretaries. These includes but not limited to abilities to: input data correctly in a system, manipulate the computer keyboards, format and reformat documents among others.

The findings agreed with Atakpa (2012) that digital telephone and office electronically powered machines have reduced the long hours of office business to a mere pressing of buttons to attain a more effective and efficient output.

The null hypothesis one tested revealed that, there was no significant difference between the experienced and less experienced employers in public and private establishments in Enugu State regarding basic digital skills possessed by their secretaries for effective management of information. The implication of the findings of no significant difference was that the type of the establishments had no significant influence in the opinions of the employers on the basic digital skills. 
Data obtained regarding research question two showed that, advanced digital skills are fairly possessed by secretaries in both private and public establishments in Enugu State for effective management of information.

The findings were in agreement with Ugwunwoti (2018) that employers of labour demand graduates who are prepared to leverage technology in a scalable fashion to advanced their organization strategies and operations.

The null hypothesis two tested showed that experienced and less experienced employers in Enugu State did not differ significantly in their mean ratings of advanced digital skills possessed by their secretaries for effective management of information. The implication of the findings of no significant difference was that the experience had no significant influence in the opinions of the employers.

\section{Conclusion}

Based on the findings of the study, basic digital skills are highly possessed by secretaries in both public and private establishments in Enugu State for effective management of information. Again, advanced digital skills are fairly possessed by secretaries in both private and public establishments for effective management of information.

\section{Recommendations}

Based on the findings of the study, the following recommendations were made:

1. There should be regular seminars and workshops for the secretaries on improving their digital skills.

2. Employers of labour should provide ICTs to their secretaries as working tools.

3. Secretaries should be made to handle cyber security to prevent hackers.

4. Teaching of information management should be made compulsory in all Department of Business Education.

\section{REFERENCES}

Atakpa, R.A. (2012). Computer skills needed by Business Education (secretrial) graduates working in an electronic office. Delta Business Education Journal 2(1): 97-102.

Business Directory (2020). Enugu State Summary of Business Directory: Statistics Unit.

Cornell University Digital Literacy Resources (2019). Digital skills: Retrieved on 15/7/21

Ile, C.M. (2010). Competencies needed by Business Education graduates to survive in an advanced information age. Business Education Journal, 5(11) 77-83.

International Finance Corporation (2019). Digital skills demand: Retrieved on 2021.

Ngwoke, S.C. (2019). Secretaries skills needed by office technology and management students of universities in Enugu State. Unpublished undergraduate project, Department of Business Education, ESUT.

Nworgu, B.G. (2015). Educational Research: Basic issues and methodology. Nsukka: University trust publishers.

Ikenga, C. N., \& Enyi, D. (2021). Determinants of Persistent Administrative Challenges Of Female Principals' Effectiveness In Secondary Schools In Enugu State, Nigeria. Contemporary Journal of Education and Development, 1(2), 22-43

Helen Ebere, B., \& Akubuilo. D. (2021). Appraisal of Available Instructional Media In The Implementation Of Computer Studies Programme In Upper Basic Schools In Enugu State, Nigeria. British International Journal of Education and Social Sciences, 8(7).

Obayi, A.U. (2020). Office Secretarial and Management Dynamics (2 ${ }^{\text {nd }}$ edition) Enugu: Jon-Jay classic publishers. 
The world Bank Report (2018). Digital jobs for the youth: Young women in the digital economy.

Udoye, R.N. (2013). Employer's appraisal of tertiary Business Education graduates on modern office job competencies (unpublished) thesis. Department of technology and vocational Education, Nnamdi Azikwe University, Awka.

Ugwnwoti , E.P. (2018). Competencies possessed by secondary school Business Education graduate employers for effective performance of contemporary office jobs in Enugu State. Unpublished Ph.D thesis, Department of Technology and Vocational Education, ESUT.

Ugwunwoti, E.P. (2021). Perception of office managers on technology skills possessed of secretaries in colleges of education for managing information in Enugu State. Advanced Journal of Education and Social Sciences $3(10), 10-22$

Umoru, T.A. (2019). Plotting pathways across transformational changes in Business Education: A desideratum for empowering learners to engage the world. ABEN conference proceedings. 